Journal Universitas Muhammadiyah Gresik Engineering, Social Science, and Health International Conference (UMGESHIC)

UMGCINMATIC : $1^{\text {st }}$ Rethinking Education during Covid-19 Era: Challange and Innovation

\title{
FRAMEWORK : THE EFFECT BETWEEN PEER CONFORMITY AND SELF-CONTROL ON A HEDONIC LIFESTYLE
}

\author{
Author \\ Herlin Pamungkas', Asri Rejeki² \\ 1,2 Psychology Faculty, University of Muhammadiyah Gresik \\ herlinpamungkas05@gmail.com¹, asrirejeki@umg.ac.id²
}

\begin{abstract}
This research is preliminary research. Each individual has his own unique style, so each individual must have the desire to look and be well-guided by his environment. This is due to the lifestyle displayed following fashion trends. Nowadays, hedonistic lifestyles are increasingly rife and most of them earn money from their parents and the behavior that is in demand by them is a walk to malls and cafes. For example, the campus environment, when the individual is in a friendship group then the individual will follow the behavior or appearance in the group so that the individual will feel comfortable, not feel inferior, and make it easier for the individual to interact with the group. These problems are due to a lack of self-control in the individual. If the individual has low self-control then the higher the hedonistic lifestyle in the individual, and vice versa. To determine the effect of peer conformity and self-control on hedonic lifestyle on students. This research uses a quantitative research type with a survey method. The subjects in this study were students, with a total population of 249 students. The scale used is a hedonic lifestyle scale, a peer conformity scale, and a self-control scale. Data analysis using multiple linear regression test.
\end{abstract}

Keywords: Hedonic Lifestyle, Peer Conformity, Self-Control, Student 


\section{UMGCINMATIC : $1^{\text {st }}$ Rethinking Education during Covid-19 Era: Challange and Innovation}

Volume 1 No 2

\section{INTRODUCTION}

Currently, the development of the time of the modern, where each individual easily in accessing various media information. Teens included in among the effect on the development of modernization of the moment. The development of an increasingly modern bring individuals on the behavior patterns unique, which distinguish it with individuals who one and individuals the other is in terms of the issue lifestyle. It is lead to change on the value as well as the pattern or lifestyle.

Currently, teenagers today abuse the lifestyle especially teenagers living in the city of the majority of them more follow the trendmode the days now, for example dressed like a westernized, ngemall, hanging out in the cafe, etc. The habit to travel to a place expenditure such as supermarkets, department store, and mainly to the mall to fill his spare time. Places such as is considered by the girls as a place to show or highlight the existence of themselves. sometimes teenagers to buy a goods or products not based on the urgent need, but only for the pleasures personal.

Each individual has a style unique respectively, so that each individual must have a desire to appear and considered good by the environment. In today this, sometimes can not tell which individuals who are able to or less able to in terms of financial. It is caused lifestyle shown that follow the trend mode, because usually among students using the goods being trend. The trend lifestyle hedonism this is the range of style that looks among students. Intercourse peers very influence on inidvidu to follow the lifestyle hedonic in order to stay received in the group. It is because the intensity of meetings and social development in individuals more involved peers than their parents (Trimartati, 2014).

The tendency of the occurrence of lifestyle hedonic this looks occur especially in the big cities, because the current rise of cafes, restaurants, mall, hangout other, especially in the Gresik. According to the Central Statistics Agency (BPS) 2018 that shows that the number of restaurant or café that is in East Java as much 4,169 and in Gresik amounted to as much 106. Based on the survey conducted by Nadzir\& Ingarianti (2015) in the students showed that the streets to the mall (24\%) and hang out in the cafe $(24 \%)$ to activities which is often done by students, watch to the movies (17\%), go to book store (10\%), karaoke with friends (9\%), learn to understand the material of lecturer (7\%), playing games (5\%) and go to the library (3\%). Based on the survey can be concluded that the lifestyle behaviors hedonic on these students the rife and most they get money from his parents and behavior of interest by them is the streets to the mall and hang out in the cafe.

There are students who is very pay attention to their appearance while on campus environment and the outside environment campus. Some students who use mobile phone or smartphone latest release, after the home from campus go for nongrong to the cafe or fast food restaurants, and a walk to the mall.

It is in line with the phenomenon of the existing on the students faculty psychology, that the individual buy a goods. So that inevitably, they must follow the trend that developed today. The trend lifestyle hedonic is also gave rise to individual behavior through interaski social between individuals with each individual others. to obtain the pleasure and freedom for the reach the enjoyment of life. Lifestyle hedonism this can lead to the adverse effects to the development of education, one of which increased sense of laziness, forget the obligations in school because busy to find entertainment or pleasure. The lack of self- control also lead to individuals falling prey on the environment socially a bad later. 


\section{UMGCINMATIC : $1^{\text {st }}$ Rethinking Education during Covid-19 Era: Challange and Innovation}

Volume 1 No 2

Everyone is actually have a lifestyle hedonism, which distinguish it is just a level. There are the level of lifestyle hedonic the medium and weight, lifestyle hedonic weight is already considers that the pleasure is the goal of his life (Trimartati, 2014). Many of some students who still rely on their parents, certainly when there is an unfulfilled desire it will feel depressed or fear when stamped not follow the trend of the present.

Basically every individual has free time, and how each individual is in order to take advantage of his spare time to do things to be done. But, there are teenagers who use his spare time to do the pleasure self, such as gathered with friends, shopping, etc. As disclosed McClelland in (Jannah\& Sylvia, 2020), each individual has free time, should everyone take advantage of his spare time is to think about how to improve the present situation towards a better, and implement the tasks faced with a good way. It can be known from the ways individuals in use his spare time on the activities concerned with the appearance or prestige in the interaction.

One of the factors influence of lifestyle hedonic in adolescents this is due to peers or conformity. peers also provides an influence on individuals in interact in the environment. As expressed by Santrock (2003) that the conformity appears when the individual mimic the attitude or behavior of others due to real pressure as well as envisaged. Conformity is a behavior in order to look the same and comfortable to be on the environment group.

\section{METHODS}

The method will be used in this study is the quantitative research by using the approach correlation. research approach correlation used to find the correlation between two or more variables (Winarsunu, 2017). Scale model used in this study the model Likert scale. Data collection methods used in this study is to use the conformity scale peers, scale of self-control, and scale lifestyle hedonic. The subjects in this study were students, with a total population of 249 students. Criteria subject of this study that is (1) active students Faculty of Psychology University of Muhammadiyah Gresik, (2) are willing to be a study participants. Data analysis techniques used to know the relationship between the conformity and self-control of the lifestyle hedonic that is using techniques multiple regression analysis.

\section{DISCUSSION}

Each individual has a style unique respectively, so that each individual must have a desire to appear and considered good by the environment. Lifestyle is subject of the individuals in spending time as well as money they have get to gain pleasure, happiness in him. Lifestyle in individuals excessive will lead to lifestyle hedonism. Factors the formation of lifestyle hedonic one of which is a factor of friends or conformity peers. So that the need for self- control on individual self. 


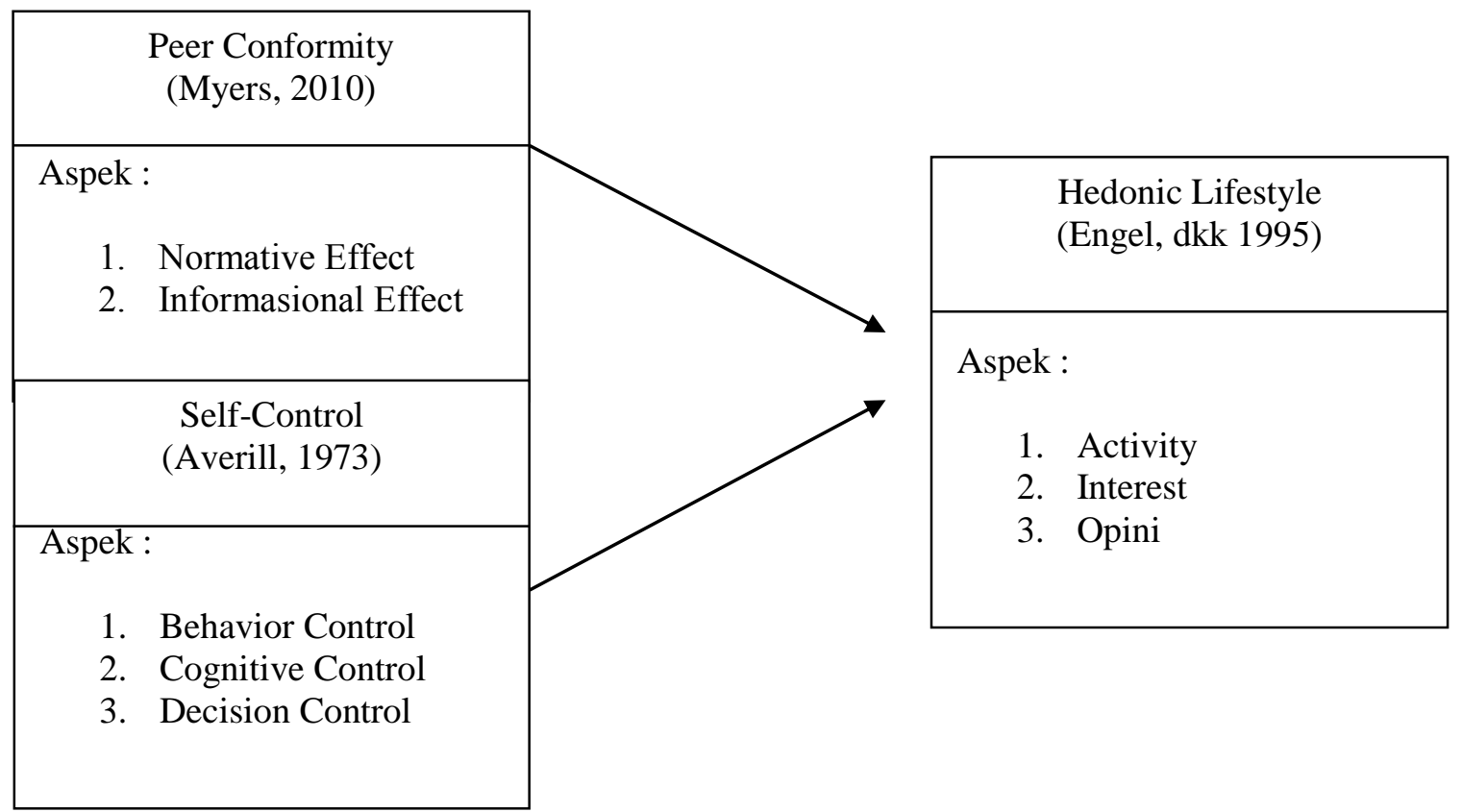

Figure 1. Factors the formation of lifestyle hedonic one of which is a factor of friends or conformity peers

Lifestyle hedonic according to Solomon (2009) in (Utari, 2017) lifestyle hedonic is the behavior or habit of an individual to spend time to have fun with playmates and want to be the limelight in the environment. The trend lifestyle hedonic include more pleased to fill the free time in the mall, cafes, and fast food restaurants, as well as has a number of branded goods. It is usually done a number of students to menghabisakan his spare time for the reach the pleasure to live with activities or activities such as nonkrong in the cafe, fast food restaurants, mall, and others. lifestyle behaviors hedonism this is one of styles that looks among students.

Factors the emergence of lifestyle hedonic this because of the internal factors and external factors. Intercourse peers very influence on inidvidu to follow the lifestyle hedonic in order to stay received in the group. It is because the intensity of meetings and social development in individuals more involved peers than their parents (Trimartati, 2014). So that the emergence of conformity at a group of friendship, the order to avoid a refusal or alienation in the group.

According to Baron and Byrne (2005) conformity is a type of social influence which the individual change attitudes and their behavior to fit the social norms exist. The existence of conformity this to look of the tendency individuals to always adjust the behavior shown with reference group in order favored by others or at least to avoid rejection of them or alienation groups. Self- control is about how powerful individuals in holding his beliefs and value to be used as a reference when the individual act or take a decision. So, it is required self- control to be able to reduce or control behavior can lead behavior of hedonism. 


\section{CONCLUSION}

Based on the phenomenon occurs and literature about the tendency lifestyle hedonic on the students it can be influenced by the conformity peers and self-control. Factors affecting the lifestyle hedonic this is the factors that comes in the individual self and also comes from outside the individual. The problems regarding the tendency lifestyle hedonic is adapted to the expert opinions and the previous studies sourced from the environment of friends or conformity peers and lack of self-control in individuals.

\section{REFERENCES}

Agustiani, H. (2006). Psikologi Perkembangan (Pendekatan Ekologi Kaitannya dengan Konsep Diri dan Penyesuaian Diri pada Remaja). Bandung: Refika Aditama.

Alwisol. (2017). Psikologi Kepribadian. Malang: UMM Pres.

Averill, J. R. (1973). Personal Control Over Aversive Stimuli And Its Relationship To Stress Psychological Bulletin, Vol. 80, No. 4 , 286-303.

Azizah, F. N., \& Indrawati, E. S. (2015). Kontrol Diri dan Gaya Hidup Hedonis pada Mahasiswa Fakultas Ekonomi dan Bisnis Universitas Diponegoro. Jurnal Empati, $\quad$ Vol. 4 No.4 , 156162.

Baron, R. A., \& Byrne, D. (2005). Psikologi Sosial. Jakarta: Erlangga.

Chaplin, J. P. (2001). Kamus Lengkap Psikologi. Jakarta: Raja Grafindo Persada.

Davidoff, L. L. (1981). Psikologi Suatu Pengantar. Jakarta: Erlangga.

Engel, J. F., Blackwell, R. D., \& Miniard, P. W. (1995). Consumer Behavior Eighth Edition. Florida: The Dryden Press.

Ghufron, M. N., \& Risnawati S, R. (2017). Teori-Teori Psikologi . Jogjakarta: Ar-Ruzz Media Group.

Hersika, E. I., \& Kurniawan, K. N. (2020). Hubungan Antara Kontrol Diri Dengan Gaya Hidup,Hedonisme Remaja Di Kafe Kota Padang. Jurnal Psyche 165, Vo. 13, No. 1, 1-9.

Jannah, I. N., \& Sylvia, i. (2020). Hubungan Kelompok Teman Sebaya Terhadap Gaya H Hedonisme Pada Mahasiswa. Jurnal Perspektif : Jurnal Kajian Sosiologi dan Pendidikan, Vol. 3, No. 1, 187-200.

Marsela, R. D., \& Supriatna, M. (2019). Kontrol Diri : Definisi dan Faktor. Jounal of innovative Counseling : Theory, Practice \& Research, Vol. 2, No. 2, 65-67.

Nadzir, M., \& Ingarianti, T. M. (2015). Psychological Meaning Of Money Dengan Gaya Hidup,Hedonis Remaja Di Kota Malang. Seminar Psikologi \& Kemanusiaan. ISBN :978-979796-324-8, 582-596.

Santrock, J. W. (2003). Adolescence Perkembangan Remaja. Jakarta: Erlangga.

Sugiyono. (2016). Metode Penlitian Kuantitatif, Kualitatif, dan R\&D. Bandung: Alfabeta.

Sukarno, N. F., \& Indrawati, E. S. (2018). Hubungan Konformitas Teman Sebaya dengan Gaya Hidup Hedonis pada Siswa di SMA Don Bosko Semarang. Jurnal Empati, Vol.7 No. 2, 314-320.

Trimartati, N. (2014). Studi Kasus Tentang Gaya hidup Hedonisme Mahasiswa Bimbingan dan Konseling Universitas Ahmad Dahlan. Psikopedagogia, Vol. 3 No. 1, 20-28.

Utari, M. (2017). Pengaruh Media Sosial Instagram Akun @princessyahrini Terhadap Gaya hidup Hedonis Para Followersnya. JOM FISIP, Vol.4 No. 2, 1-22.

Winarsunu, T. (2017). Statistik dalam Penelitian Psikologi dan Pendidikan. Malang: UMM Press. 